\title{
NOTES ON THE MAMMALS OF ECONOMIC VALUE IN CHINA
}

\author{
By Malcolm P. Anderson,
}

Recently Conducting the Duke of Bedford's Exploration in Eastern Asia.

In China, where there is so much poverty, and where so little goes to waste, almost every animal has some economic use. In the following notes, gathered during three years of travel, I have tried to touch only on the mammals which are of most economic value to the Chinese themselves. $\mathrm{My}$ aim is to give some notion of economic conditions in China to-day, not to furnish information for anybody desirous of exploiting the furs or hides of the country.

\section{Domestic Mammals}

Most of the domestic mammals of China are so well known to Western people that it is scarcely necessary to mention them. I will treat them briefly.

Cattle of a small hump shouldered variety are commonly used in northern China as beasts of burden. On the great highway which connects Peking with Urga and Uluassutai in Mongolia, one sees caravans of hundreds of carts, each drawn by an ox. They bring salt and borax to Peking from remote parts of Mongolia. In other regions they are used as pack animals or for general work on the farm. Cows are never milked by the Chinese, cheese and butter are unknown. The skins of cattle are smoke-tanned and used for making boots, saddlery, etc.

$Y a k$.-Farther westward, where the provinces of Kansu and Sze-chwan border on Tibet, the place of the ordinary cattle is taken by a cross between the wild yak and the cow. These hybrids are much larger than their domestic parent, long horned, and black in color, with a white median stripe down the back. Like the wild yak, they have long hair hanging from the breast, legs, and tail. In western Kansu they are used as cart animals; in western Szechwan they are the pack animals which carry nearly all the freight of tea into Tibet. The tribes-people on the Tibetan frontier, who are more Tibetan than Chinese in their customs, milk these animals, 
and make butter and cheese, and an intoxicating liquor like kumiss. A few of the Chinese who come in contact with these pastoral "western barbarians" use these products. The hides of the yak are valuable for the leather they produce, and the flesh, which is excellent, is much used for food.

Water Buffalo.-Throughout the lowlands of the Yang-tze basin, and even back into Sze-chwan to an altitude of 3,000 or 4,000 feet, one often sees the slow-going water buffalo. It is used chiefly for cultivating paddy fields, but is too slow for a pack or draught animal on the road. Its hide is of considerable value. I do not think the water buffalo is ever killed for food, it is too expensive an animal, but when it dies of old age or disease, its flesh is eaten. Of course under these conditions it is wretched food.

Camel.-In Chi-li and Shansi, and to a less extent in the provinces of Shensi and Kansu, the Bactrian camel is much used as a pack animal, or sometimes for drawing large carts. Its hair is valued and is exported to Europe. The Chinese use it for making ropes and coarse sacking. It seems probable that it is the high cost of the camel which restricts it to the wealthier vicinities.

Sheep.-Black-headed, fat-tailed sheep are commonly raised in the poorer mountain regions of northern and western China. Their flesh is a staple food, and may be purchased in any city or market town of these regions. Woolen garments are not much used by the Chinese in general, but in some districts wool is spun and knitted into stockings, mittens, and winter garments for little children. In northern China, where the winters are severe, felt made of sheep's wool is much used in the shape of sleeping rugs, waistcoats, capes, caps, and stockings. Sheepskins with the wool on are made into coats and gowns of all grades, from those used by the poor muleteer, costing only a few cents, to those worn by well-to-do officials, costing upwards of ten dollars.

Goat.-Like sheep, goats are raised in the poorer regions of northern and western China. There are a number of varieties, but all of less value than the sheep. Goats are able to pick up a living where even sheep have a hard time, and so are often owned by the very poorest country people who live high on the mountainsides where the soil is scarcely productive enough for tilling. The flesh and wool of goats are put to the same uses as those of sheep, but the quality is poorer. 
Swine.-As a producer of food the domestic hog is undoubtedly the mammal of greatest value. This animal has its place in nearly every household, whether rich or poor, in the dense city or the country. Even the smallest market has its stall where pork is sold. If a private family kills a hog they take what flesh they do not wish to keep to market. The Chinese understand smoking, salting, and drying of flesh, after their own fashion, and hams and bacon are to be purchased. Every part of the hog is put to some use. Europeans in China do not eat. pork owing to the filthy conditions under which the animals are kept, but there is no flesh the Chinese like so well. They call it "da-roe," the great meat.

Pigskin is occasionally made into leather, but is more often used as rawhide for straps and thongs. Brushes are made from the bristles.

Horse.-There are various breeds of horses in China, but they are mostly of small size. They have, however, excellent powers of endurance. Horses are seen most in the northern provinces, where they are chiefly used for riding, but also as pack and draught animals. Their hides are made into leather, and their flesh is sometimes eaten by the poor.

Mule.-Mules are bred in Mongolia, in the region northwest of Peking, and also in the far west of China on the borders of Tibet. They are larger than the usual Chinese horse, faster travelers with a load, and of more endurance. Though much commoner than horses, they bring a higher price. She-mules are much used as cart animals in and about Peking, but on the pack trails in the mountains one sees only stud-mules.

In order to give some idea of the cost of travel with mules, I will relate a personal experience. In the city of Si-ngan-fu, the capital of Shensi, I hired mules at the rate of forty-three cents per animal per working day, and about twenty-five cents per day when we did not travel. This included the hire of the three muleteers, who cared for five animals and acted as our servants besides. The mules were supposed to carry 200 catties (about 260 pounds) each, and cover from eighteen to twenty-seven miles a day, according to the character of the country. In truth, my loads were not so heavy as this, but we often did over twenty miles a day, even in rough country, and, in the plains, sometimes over thirty miles.

Donkey.-Donkeys are exceedingly common in the northern 
provinces of China, where they are used as pack animals, and to do general farm work. Their initial cost is small compared with the price of a mule, and they are much cheaper to keep, so they are more popular with the poor people.

Dog.-Every country family has a dog, and often several. In some places they seem to be as numerous as the people. There are of course numbers of breeds, but the common Chinese dog is an animal much resembling a wolf, only smaller, and not always colored like a wolf. They are chiefly for watching purposes, and seldom fail to bark when one passes. Though their tempers are bad, they are too ill-fed to have much courage, so seldom attack one. Dogskins with long hair are much in demand among the poor as sleeping rugs. The notion that dogs are a common food is false. Except in a time of actual famine dogs are rarely or never eaten, even by the poorest. I speak for the provinces of north, central, and western China.

Cat.-There are several varieties of domestic cats kept by the Chinese. Most attractive looking is the long-haired gray cat of Peking. In central Sze-chwan all cats are highly valued as ratters, but it is hard to see how they kill any rats, for their owners keep them tied up for fear of their being stolen. Catskins are of some value as fur in all parts of China, and when dyed and disguised are sold as the fur of other animals.

Rabbit (Lepus cuniculus).-The domestic rabbit is seldom seen except in central Sze-chwan, where it is commonly raised. The flesh is eaten fresh, or the animals are skinned and dried whole for food. Coats, gowns, and leggings are made of the fur.

\section{Wild Mammals}

Deer (Cervus sp.).-A large deer more resembling the American elk (Cervus canadensis) than anything else inhabits the wilder mountains of far-western China. It is much hunted by the tribespeople for the sake of the antlers, which bring a good price with the Chinese, who use them for making eye medicine. The flesh and skin of the animal also have their value, and the tendons of the legs are particularly prized. These, when boiled into a gelatinous mass, are served by the Chinese at their feasts.

Roe Deer (Capreolus bedfordi).-This is a very much smaller deer than the elk, and being also very common in some regions of 
the northwest is of comparatively little value. The antlers, which are small, are used for making medicine, and the flesh is relished. Deerskins are seldom tanned, but are often stretched and dried, and used thus as sleeping rugs.

Musk Deer (Moschus moschiferus and M. sifanicus).-These species, though rare, are still met with in the remoter mountains of central and western China. The flesh and skins are of little importance, but the musk, produced only by the male, in a gland near the navel, is of high value to the Chinese as a medicine and perfume. The long sharp incisor teeth, which grow as tusks from the mouth of the male musk deer, are much used as toothpicks by the merchants and literati of China.

Takin (Budorcas sp.).-This peculiar animal, of a size approaching that of an ox, and characters between those of an ox and those of a goat, inhabits portions of Tai-pei-san, a lofty mountain in central China. I cannot claim that it plays an important part in the economy of China, but it is regarded as of great value by those who know of its existence. Skin, flesh, bones, blood, every part in fact is supposed, by the superstitious and ignorant Chinese, to have some special virtue. It is not very often that one of them is killed, for living as they do in precipices at high altitudes (9,000 to 11,000 feet), and going in herds, hunting them requires not only energy, but great skill, and, in the case of the poorly armed Chinaman, much risk.

Goat-antelope (Nemorhadus argyrochates, and other species). -The species of Nemorhadus found in western China are perhaps not of much economic importance, yet one often sees their bones and horns in the medicine shops, and the skins of the smaller species on the backs of the tribes-people.

Wild Swine (Sus sp:).-In the hills and mountains of northern, central and western China wild hogs are numerous, and are much more of a hindrance than an economic help. The peasants are much in dread of their raids on cultivated fields, and during the seasons when crops are most in danger the fields are watched night and day. For this purpose little shacks of poles, covered with thatch of straw or cornstalks, are put up in commanding positions, and members of the peasant's family take turns in watching there. The flesh of the wild hog is relished by the Chinese. They make little use of the skins, but in some localities they are used for containers for the liquor distilled from maize, or millet. 
Mink (Lutreola siberica).-This common, medium sized mink is valued somewhat for the fur it produces, which is not good, but it is valued more especially for the hairs of the tip of the tail, of which the Chinese make their writing brushes. The animal lives very frequently about human habitations. It destroys rats, but is also a serious enemy to poultry.

Indian Marten (Martes flavigula borealis).-This rather rare marten is one of the most beautiful animals in the fauna of China. Its fur is valued quite highly, being used for the lining of garments. It is not often seen.

Wild Cat (Felis microti).-The wild cat of China produces a much used fur, for the animal is common in the mountains of the north. The fur is soft, even, and thick, and the skin is light. On account of the animal's abundance the fur is not an expensive one. It is used for the lining of coats and waistcoats and for the making of fur stockings. Mongols and Tibetans wear it as collars and caps.

Tiger (Felis tigris).-The Chinese claim that there are many tigers in the more remote mountains of all parts of the Central Kingdom, but it is my conviction that the tiger is very rare and that the leopard is often mistaken for the tiger. That tigers are occasionally found is evidenced by the skins one sometimes sees in the shops of larger cities. They are tanned whole and used by officials, or other wealthy persons, to cover divans in reception halls. The flesh and bones are regarded as of great medicinal value, the notion being that, as the tiger is such a powerful animal, any part of him must be strengthening food for the weak and sick. The bones are powdered and consumed in that form with food. They are given to children with rickets.

Leopard (Felis pardus).-The leopard is quite a common animal in the rugged mountains of northern and western China. Its footprints are often seen, and its cry is sometimes heard by the traveler, while the inhabitants tell many stories of its thefts of calves, sheep, hogs, and dogs.

In Chentu, Sze-chwan, a good leopard skin can be bought for $\$ 5.00$ or $\$ 6.00$. In southern Shensi I once purchased a good skin and entire skeleton from some hunters for \$3.00. Leopard skins, like those of tigers, are used for rugs on divans and saddles. The flesh and bones are supposed to have medicinal properties. In Tibet an occasional black leopard is found. These are probably melanistic 
individuals of $F$. pardus. At any rate, they are regarded by the Chinese as of greater value than the ordinary form. On the Tibetan frontier one also sees examples of the highly prized and truly beautiful snow leopard (Felis uncia), the skins of which, like so many other furs, are made into lining for gowns.

Lynx (Felis lynx).-A good many skins of the lynx come to China from the "Inside County," $i$. e., Tibet. These are very beautiful, and of a very soft fur exceedingly pleasing to the touch. The Chinese treat these skins as they do all furs of value. After tanning, the skins are cut into small pieces and these are sewed together in such a way that the fur of one quality or one color, as the case may be, all comes together. For instance, one gown will be made out of the fur of the backs, another out of that of the paws and legs, and another out of the skin of the chin and throat.

At Tau-choe, a fur trading town on the border of Kansu and Tibet, I once priced a lynx skin lining for a long gown. I was asked fifty ounces of silver, but $I$ have no doubt that it could have been purchased for thirty ounces, about $\$ 18.00$.

Wolf (Canis lupus).-The wolf ranges singly or in pairs throughout northern China, from Shantung to Kansu, and is quite common in certain localities. It resembles the American timber wolf, and is so much like certain large Chinese dogs that one does not always know which is which. Occasionally wolves seem to take advantage of this likeness and come close to dwellings and people in broad daylight. Wolf skins are used in China for covering divans, and are worth several dollars apiece.

Fox (Vulpes vulpes).-The red fox is one of the most common fur-bearing carnivorous animals in China, and the one of which the fur is most popular. There is a wide range of color in this species, from a rather unpleasing reddish-yellow to a deep reddish-brown. The deeper the red the better the Chinese like it, and the better price the skin will bring. Prices of fox skins vary greatly in different localities, but in Kansu I have seen a rather poor raw skin sold for about thirty-three cents and a good, red, winter skin for nearly one dollar. As described in the case of the lynx, the Chinese cut up the fox skins and piece them together to get an even quality of fur. The white soft fur of the throat is regarded as the choicest part, and I fancy the skin of the legs is the least desirable. Coats, waistcoats, and gowns are made of this fur. 
Otter (Lutra vulgaris).-Though ranging widely through China, the land or common otter is neither common nor easy to secure. One occasionally sees a raw skin hanging in a shop, and these range in price from about $\$ 1.20$ to $\$ 3.00$ or even $\$ 4.00$, according to the quality and size. A few times I have seen caps of otter skin worn. Long gowns lined with it are seen in the shops. These are of high price.

On the upper Yang-tse-kiang and its tributaries the otter is used for fishing. The fisherman has the animal tied to his raft by a long chain, and when they reach a favorable spot for fish the otter voluntarily dives off the side. Whether he makes a catch or not, he returns very soon to the raft, and the fisherman proceeds to another spot.

Bear (Ursus sp.).-Bears are among the rarest mammals in China, but I know of a species of black bear which occurs in western Sze-chwan. In Kansu I have seen the fragmentary skins of a "blue" bear of unknown species, but reminding one of the "blue" bear of the Mt. St. Elias region. Bear skin is, if course, too heavy for garments, and is used in China only in the shape of rugs, so far as I have seen.

Badger (Meles leptorhynchus).-This "pig-nosed" badger, a fairly common animal in northern China, furnishes a coarse fur used by the peasantry for winter jackets and caps. Pieces of the raw skin are often used by Chinese hunters to protect the breaches of their matchlock guns against dampness. Badger flesh is eaten with relish by the poor.

Hares (Lepus swinhoei and subsp.; Lepus sechuenensis).Swinhoe's hare occurs in Shantung, Chi-li, Shansi, and Shensi, often in large numbers. It is much hunted by the Chinese, and its flesh may be bought in the market of any large city. On account of the tenderness of the skin the fur is not of much value, but is sometimes used for lining caps and ear mufflers.

The Sze-chuen hare is a much rarer animal of larger size, living at high altitudes in northwestern China. When secured its fur is used in the same way as that of the other hare.

Squirrels (Sciurus vulgaris; Sciurotamias davidianus et subsp.; Sciuropterus $s p$.). - The common squirrel of Eurasia certainly inhabits Siberia and Manchuria, and possibly northern Chi-li. But whether the skins are all imported from the north or not, they are 
very widely used throughout China for the lining of ladies' gowns. The skin is very light and the fur soft and thick, but not very long. The white or creamy fur of the underparts is considered the choicest, so the skin is opened down the back, preserving the belly intact. When sewn into a garment the creamy white bellies contrasting sharply with the gray of the sides produce a very pleasing effect.

Père David's squirrel produces a fur used in the same way. It is an animal eight or nine inches in length of head and body, and of colors produced by a mixture of gray and buff. It has not the excellent quality of fur found in $S$. vulgaris nor the beautiful contrast of upper and underparts, therefore it is less prized.

There are several forms of flying squirrels in China, all valued for the softness of their fur, but being nocturnal and arboreal in habit, they are seldom seen and difficult to secure.

Rodent Mole (Myosphalax cansus, $M$. fontanieri).-Another rodent of some economic value is the rodent mole of northern China. This is an animal some seven inches in length, resembling a mole in its habits, and to a certain extent in its appearance, but it lacks the sharp nose. The fur is mole-like and is used by the Chinese for lining light garments and for making ear-mufflers. The flesh is thought to have medicinal value.

On the Tibetan border of Kansu Province the tribes-people regard the flesh of the rodent mole as very delicate food. In April, when the animals are emerging from hibernation, these natives capture them with bow and arrow traps set to spear them through the surface earth as they pass through their burrows. They are then skinned and cleaned and spread out by spitting them with little sticks. Thus they are cooked and eaten.

Macaquc (Macacus tcheliensis).-This monkey can scarcely be called a fur-bearing animal, but it furnishes a skin much used by the Chinese for waistcoat linings.

An ape, probably a species of Semnopithecus, inhabits the mountains of western China and his skin is very. much prized by the Chinese. The hair is two or three inches long and of a sandy color. I was told that a good skin was worth forty ounces of silver, about $\$ 25.00$. This skin is used by the Imperial Family for making leggings.

The reader who has taken the pains to peruse these pages will 
see that the most important economic mammals of China are very much like our own. In most cases the species are different in the two countries, but from an economic point of view this makes no difference. I have presented to the reader a rather long list, and I hope I have been able to correct in his mind the common notion that China is lacking in wild mammal life. A full list of the mammals of China would mount up into the hundreds. 